\title{
Thermometry of Apatite Saturation (The Kozhym Massif, The Subpolar Urals)
}

\author{
Y. Denisova ${ }^{(\bowtie)}$, A. Vikhot, O. Grakova, and N. Uljasheva \\ Institute of Geology of the Komi SC UB of RAS, \\ Syktyvkar, Komi Republic, Russia \\ yulden777@yandex.ru
}

\begin{abstract}
The results of the study of accessory apatite from the Kozhym massif rocks have been presented in this paper. Apatites of the same morphological type were found in granites. The Kozhym massif granites formation temperatures by apatite were determined by the Watson and Bea saturation thermometry. These temperatures were compared with the previously obtained ones for accessory zircon of the same massif.
\end{abstract}

Keywords: Apatite - Granite - The Kozhym massif - The Subpolar Urals • Watson $\cdot$ Bea

\section{Introduction}

The Kozhym massif is located in the northeastern part of the Subpolar Urals on the left and right banks of the Kozhym River in the Oseu and Ponyu Rivers basins (Fig. 1) among deposits of the Puyvinian Middle Riphean Formation. This massif is the second by area among the geobodies composing the Kozhym intrusion which includes the Kuzpuayu granite massif. The most fully preserved Kozhym massif granites are medium-grained pink greenish-gray rocks. They (the rocks) are characterized by a massive coarse-platy texture with well-defined tectonic gneissiness. The studied massif belongs to the A-type according to B. Chappel classification (Fishman et al. 1968).

The accessory massif apatite is represented by yellow mat elongated crystals of a hexagonal dipyramidal-prismatic habitus. The crystals size is $0.1-0.4 \mathrm{~mm}$, the elongation coefficient is $1.5-3$. The mineral shape is represented by a combination of a prism (1010) and a dipyramid (1011). The faces surface is fractured. Characteristic inclusions are quartz, plagioclase, zircon.

\section{Methods}

Apatite is increasingly used as a geothermometer. The E. Watson saturation thermometry was used to determine the mineral crystallization temperatures. This method allowed determining the apatite and rock formation temperature by the distribution of the phosphorus oxide content between apatite and the rock containing the mineral. The level of phosphorus saturation necessary for the apatite crystallization depends on the 


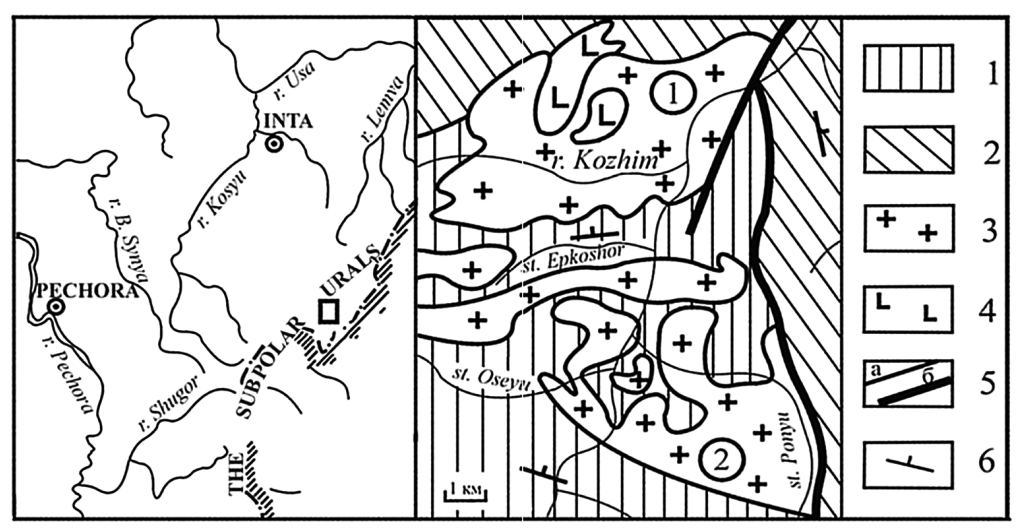

Fig. 1. The geological Kozhym granite massif map. 1 - mica-quartz schists, green orthoschists, quartzits; 2 - mica-quartz schists, porphyries, porphyrites, marbles and quartzits interlayers; 3 granites; 4 - gabbro; 5 - contact lines: a - stratigraphic and magmatic, $b$ - tectonic; 6 - planar structured bedding elements. Massifs (numbers in circles): 1 - the Kuzpuayu; 2 - the Kozhym.

silica content in the meta-aluminic rock $(\mathrm{A} / \mathrm{CNK}<1)$ and the temperature according to the Harrison and Watson calculations (Harrison et al. 1984):

$$
\begin{aligned}
& \mathrm{InDp}=\left(8400+26400\left(\mathrm{SiO}_{2}-0,5\right)\right) / \mathrm{T}-3,1-12,4\left(\mathrm{SiO}_{2}-0,5\right), \\
& \mathrm{P}_{2} \mathrm{O}_{5}(\mathrm{HW})=42 / \mathrm{Dp},
\end{aligned}
$$

where $\mathrm{Dp}$ is the ratio of $\mathrm{P}$ concentration in apatite and melt, $\mathrm{P}_{2} \mathrm{O}_{5} ; \mathrm{SiO}_{2}$ is the weight fraction of the phosphorus oxide, silica in the melt, wt. \%, $\mathrm{T}$ is the temperature, Kelvin.

Bea (Bea et al. 1992) proposed the following addition to the Watson's formula for peraluminum rocks $(\mathrm{A} / \mathrm{CNK}>1)$ :

$$
\mathrm{P}_{2} \mathrm{O}_{5}(\mathrm{Bea})=\mathrm{P}_{2} \mathrm{O}_{5}(\mathrm{HW}) * \mathrm{P}_{2} \mathrm{O}_{5}(\mathrm{HW}) * e^{\frac{6429(\mathrm{~A} / \mathrm{CNK}-1)}{T-273,15}}
$$

\section{Results and Discussion}

The apatite saturation temperatures based on the data of the chemical granites composition of the Kozhym massif (Table 1) were calculated by the author according to Watson and Bea (Table 2).

The Kozhym massif rocks formation temperatures distribution histograms by apatite were compiled on the obtained temperatures for each calculation method (Fig. 2). 
Table 1. Chemical granites composition of the Kozhym massif

\begin{tabular}{l|r|r|r|r|r|r|r|r|r|r}
\hline Component, wt. \% & \multicolumn{2}{l}{ Sample number } \\
\cline { 2 - 13 } & K-1 & K-2 & \multicolumn{1}{l}{ K-3 } & K-4 & K-5 & K-6 & K-7 & K-8 & K-9 & К-10 \\
\hline $\mathrm{SiO}_{2}$ & 77.78 & 76.89 & 75.95 & 75.89 & 76.49 & 78.12 & 77.54 & 76.26 & 77.48 & 76.95 \\
\hline $\mathrm{TiO}_{2}$ & 0.16 & 0.22 & 0.48 & 0.52 & 0.48 & 0.11 & 0.24 & 0.42 & 0.31 & 0.59 \\
\hline $\mathrm{Al}_{2} \mathrm{O}_{3}$ & 11.88 & 11.95 & 12.69 & 12.52 & 10.05 & 11.34 & 11.78 & 12.22 & 11.09 & 10.92 \\
\hline $\mathrm{FeO}$ & 1.72 & 1.29 & 1.15 & 1.24 & 0.56 & 0.50 & 0.59 & 0.62 & 0.61 & 1.03 \\
\hline $\mathrm{Fe} \mathrm{O}_{3}$ & 0.84 & 1.12 & 0.52 & 1.05 & 0.92 & 1.21 & 0.87 & 1.02 & 0.89 & 0.56 \\
\hline $\mathrm{MnO}$ & 0.02 & 0.00 & 0.00 & 0.01 & 0.02 & 0.01 & 0.02 & 0.04 & 0.03 & 0.03 \\
\hline $\mathrm{MgO}$ & 0.16 & 0.25 & 0.17 & 0.33 & 0.38 & 0.39 & 0.18 & 0.29 & 0.19 & 0.18 \\
\hline $\mathrm{CaO}$ & 0.31 & 0.29 & 0.22 & 0.38 & 0.59 & 0.28 & 0.45 & 0.42 & 0.37 & 0.51 \\
\hline $\mathrm{Na} 2 \mathrm{O}$ & 3.65 & 3.33 & 4.22 & 4.02 & 3.08 & 3.15 & 3.22 & 4.51 & 3.01 & 3.89 \\
\hline $\mathrm{K}_{2} \mathrm{O}$ & 3.88 & 4.51 & 4.09 & 3.89 & 4.15 & 5.17 & 4.99 & 3.78 & 4.65 & 3.28 \\
\hline $\mathrm{P}_{2} \mathrm{O}_{5}$ & 0.01 & 0.03 & 0.02 & 0.02 & 0.03 & 0.02 & 0.01 & 0.01 & 0.03 & 0.02 \\
\hline$\Pi \Pi \Pi$ & 0.05 & 0.29 & 0.59 & 0.15 & 0.75 & 0.62 & 0.39 & 0.98 & 1.02 & 1.23 \\
\hline$\sum$ & 100.46 & 100.17 & 100.10 & 100.02 & 97.50 & 100.92 & 100.28 & 100.57 & 99.68 & 99.19 \\
\hline
\end{tabular}

Note. The chemical composition was obtained using the silicate method in CUC «Science» of Institute of geology of Komi SC UB RAS (analyst Koksharova O.V.)

Table 2. Saturation temperatures for the Kozhymmassif apatite

\begin{tabular}{l|l|l|l|l|l|l|l|l|l|l}
\hline Temperature, ${ }^{\circ} \mathrm{C}$ & \multicolumn{10}{|l}{ Sample number } \\
\cline { 2 - 11 } & K-1 & K-2 & K-3 & K-4 & K-5 & K-6 & K-7 & K-8 & K-9 & K-10 \\
\hline According to Watson & 784 & 860 & 819 & 818 & 856 & 838 & 782 & 770 & 865 & 828 \\
\hline According to Bea & 722 & 798 & 770 & 764 & 856 & 836 & 768 & 770 & 840 & 826 \\
\hline
\end{tabular}
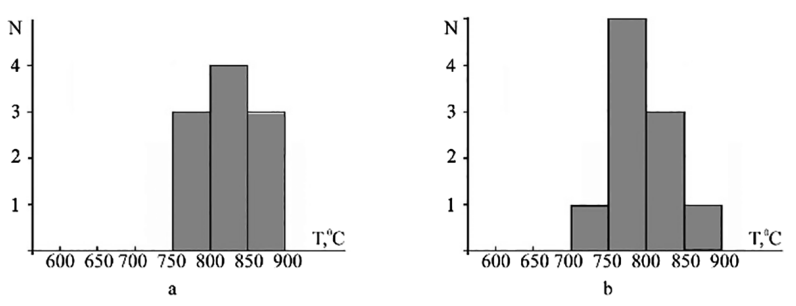

Fig. 2. Formation temperatures distribution histograms for the Kozhym massif granites. $\mathrm{a}$ - according to Watson, $\mathrm{b}$ - according to Bea

The presented histograms show that the studied granites are high-grade rocks. The Kozhym massif formation occurred at temperatures from $770{ }^{\circ} \mathrm{C}$ to $865{ }^{\circ} \mathrm{C}$ and averaged $822{ }^{\circ} \mathrm{C}$ according to Watson. The application of Bea refinements allowed concluding that the massif rocks formation occurred at temperatures from $722^{\circ} \mathrm{C}$ to $856{ }^{\circ} \mathrm{C}$ and an average of $795{ }^{\circ} \mathrm{C}$. 


\section{Conclusions}

The Kozhym massif rocks formation occurred at high temperatures. The similar massif granites formation temperature ranges: $770-865{ }^{\circ} \mathrm{C}$ according to Watson, $722-856{ }^{\circ} \mathrm{C}$ according to Bea were obtained using the Watson saturation thermometry by apatite and the Watson formula adjustment for aluminous rocks according to Bea. The data confirmed the temperatures obtained earlier by the author using the Watson saturation thermometry $\left(749-816^{\circ} \mathrm{C}\right)$ and the classical evolutionary-morphological Pupin analysis (700-900 ${ }^{\circ} \mathrm{C}$ ) for zircon of the same massif (Denisova 2016; 2018a; b). It can be affirmed that the Watson saturation thermometry and the refined Bea formula for apatite provide the same information about regime temperature evolution during the granites formation such as on the Watson saturation thermometry and the Pupin and Tyurko evolutionary-crystallomorphological analysis for zircons.

Acknowledgements. The work was supported by the Basic Research Program of RAS № 18-5-5-19.

\section{References}

Bea F, Fershtater GB, Corretgé LG (1992) The geochemistry of phosphorus in granite rocks and the effects of aluminium. Lithos 48:43-56

Denisova UV (2018a) Apatite of the Nikolaishor granite massif (the Subpolar Urals). Vestnik of Institute of geology of Komi SC UB RAS, Syktyvkar, № 9, pp 24-29

Denisova UV (2018b) Crystal morphology of zircon in solving problems of the Kozhimsky massif granites genesis (the Subpolar Urals). Trends in the development of science and education, №35, Part 3. Samara, pp 45-48. https://doi.org/10.18411/lj-28-02-2018-51

Denisova UV (2016) Temperature survey of zircon from the granitoids of the Subpolar Urals. Vestnikof Institute of geology of Komi SC UB RAS, Syktyvkar, №12, pp 37-44

Fishman MV, Yushkin NP, Goldin BA, Kalinin EP (1968) Mineralogy, typomorphism and genesis of accessory igneous rocks minerals of the Urals and Timan north. M.-L.: Sci 252

Harrison TM, Watson EB (1984) The behavior of apatite during crustal anatexis: equilibrium and kinetic considerations. Geochim Cosmochim Acta 48:1467-1477

Open Access This chapter is licensed under the terms of the Creative Commons Attribution 4.0 International License (http://creativecommons.org/licenses/by/4.0/), which permits use, sharing, adaptation, distribution and reproduction in any medium or format, as long as you give appropriate credit to the original author(s) and the source, provide a link to the Creative Commons license and indicate if changes were made.

The images or other third party material in this chapter are included in the chapter's Creative Commons license, unless indicated otherwise in a credit line to the material. If material is not included in the chapter's Creative Commons license and your intended use is not permitted by statutory regulation or exceeds the permitted use, you will need to obtain permission directly from the copyright holder.

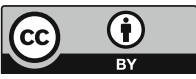

